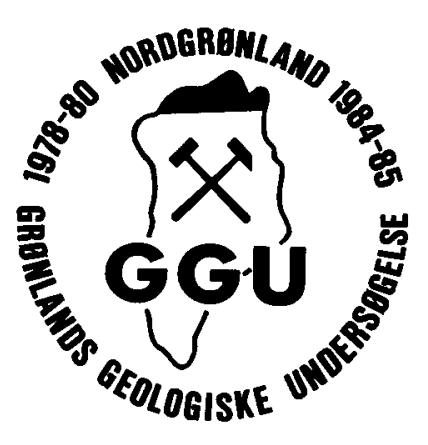

\title{
Geochemical exploration in central and western North Greenland
}

\author{
Ulla Hjorth Jakobsen and Henrik \\ Stendal
}

The 1985 geochemical exploration programme in central and western North Greenland completed the present geochemical exploration programme. A total of 424 stream sediment samples were collected during the 1985 field season. The reproducibility of drainage sampling is reasonably good for the elements $\mathrm{Ba}$ and $\mathrm{Zn}$. Follow-up of anomalous $\mathrm{Ba}$ and $\mathrm{Zn}$ values from drainage samples collected in 1984 has not revealed any new mineralised localities. The high contents of $\mathrm{Ba}$ and $\mathrm{Zn}$ are interpreted as associated with: (1) pyrite-bearing strata, and/or (2) carbonate conglomerate, and/or (3) a higher general content of these elements in some lithostratigraphic units. A known zinc mineralisation in Navarana Fjord, eastern Freuchen Land, contains baryte in addition to sphalerite.

U. J. H. \& H. S., Institute of General Geology, Øster Voldgade 10, DK-1350 Copenhagen K, Denmark.

The regional geochemical exploration programme in North Greenland using drainage sediment samples was completed during the summer of 1985 during which the Nyeboe Land and Hall Land areas were systematically sampled (fig. 1). In addition, detailed sampling was undertaken from camps in areas where the 1984 programme (Steenfelt, 1985) had indicated anomalous metal concentrations, particularly of $\mathrm{Ba}, \mathrm{Pb}$ and $\mathrm{Zn}$.

Detailed investigations in the field included rock sampling in stratigraphic profiles. These were concentrated on the Lower Palaeozoic platform margin sequence in the southern part of Nares Land, and in the Cambro-Silurian so-called 'un-named shelf and slope sequence' between the northern part of Freuchen Land and north-east Nyeboe Land (Higgins \& Soper, 1985; Davis \& Higgins, 1987). Parts of the Silurian deep-water sequence were examined on Castle $\varnothing$.

The aim of the systematic drainage sampling was to provide information for an evaluation of mineralisation potential. The systematic sampling of rocks had two main purposes: the first was to obtain material for determination of the general geochemical character of the main lithologies; the second to evaluate if certain lithologies and localities were enriched or depleted in specific elements through ore-forming processes.

Sphalerite mineralisation was reported from Navarana Fjord, eastern Freuchen Land, by Jakobsen \& Steenfelt (1985). Observations in 1985 revealed the presence of a considerable amount of baryte, in addition to the sphalerite discovered in 1984. A cross-section through 


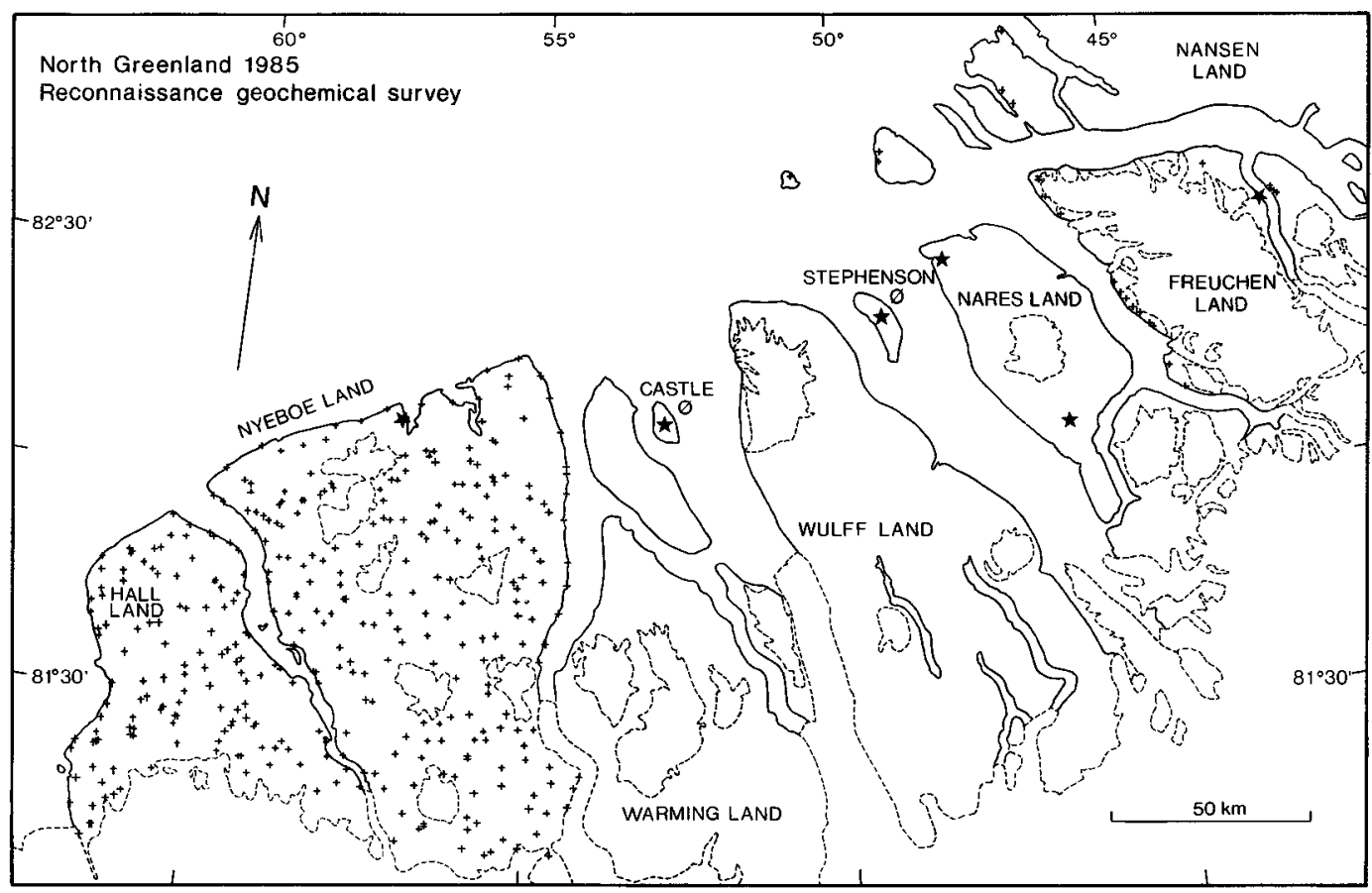

Fig. 1. Distribution of sample sites in the stream sediment survey (1985), and areas sampled for rock geochemistry. Compare with the geological sketch map in the first article in this report (Henriksen, 1987, fig. 2). The stars indicate areas investigated in detail.

the vein-type mineralisation (5-7 $\mathrm{m}$ wide) typically shows the following zonation from one side to the other: calcite-massive baryte-sphalerite/baryte-sphalerite-baryte (not massive)calcite.

\section{Sampling and analyses}

The geochemical exploration in 1985 was a continuation of the 1984 programme, and used the same sampling procedures as described by Steenfelt (1985). A low density stream sediment survey was carried out on Hall Land and Nyeboe Land, an area of $9200 \mathrm{~km}^{2}$ including small ice caps. In addition, samples were collected along the western steep coastline of Freuchen Land; a few samples were taken on the islands off western Nansen Land by A. K. Higgins and N. C. Davis, supplementing the 1984 samples.

The programme was carried out by the authors with helicopter support. The sediment samples, each weighing $300-500 \mathrm{~g}$, were taken from 5 to 10 places in each stream bed, along a 10 to $50 \mathrm{~m}$ section. The 424 sediment samples collected during the field season included some duplicates, and were taken at 225 sampling sites on Nyeboe Land, 133 on Hall Land, 18 on Freuchen Land and 6 off western Nansen Land (fig. 1). The average sampling density on Nyeboe Land and Hall Land was one sample per $25 \mathrm{~km}^{2}$.

The sampling programme had optimum conditions during the whole season, due to the small amounts of snow and relatively high temperatures at the beginning of the field season. 


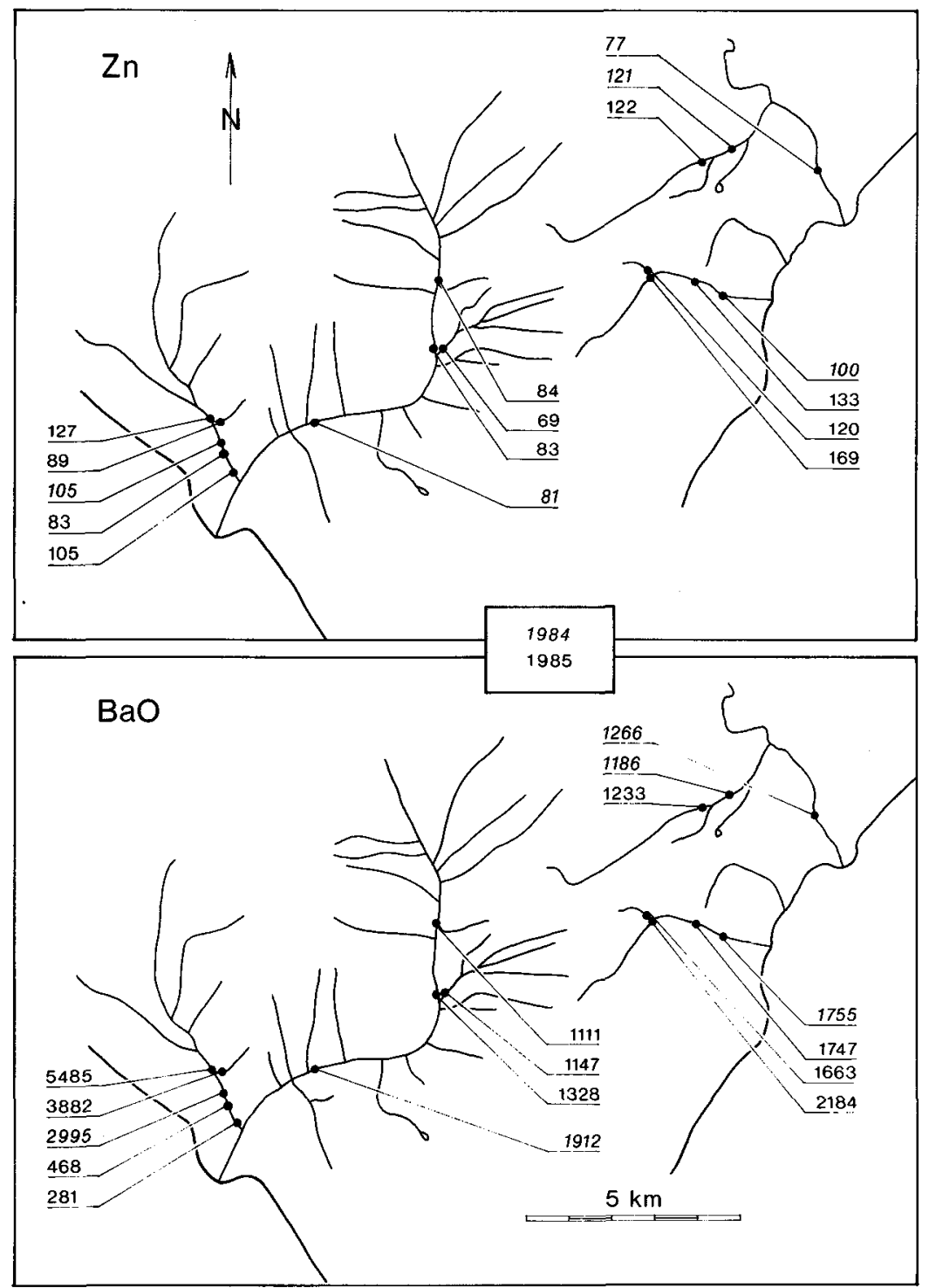

Fig. 2. Analytical values (ppm) for $\mathrm{Zn}$ and $\mathrm{BaO}$ in silt samples in southern Nares Land.

Water was running in nearly every stream bed from the beginning to the end of the season, and sediment material was available over the whole region with the exception of the southern carbonate platform, where sediment amounts were very small.

In addition to the sediment (silt) samples, 18 sand samples were collected for studies of heavy-mineral content, and a few plant samples were collected for geobotanical studies.

The sediment samples, as in 1984, were sent to Sveriges Geologiska AB for dry sieving, and XRF analysis of the less than $0.1 \mathrm{~mm}$ fraction for the elements $\mathrm{Al}, \mathrm{Ca}, \mathrm{Fe}, \mathrm{K}, \mathrm{Mg}, \mathrm{Mn}$, 
$\mathrm{Na}, \mathrm{P}, \mathrm{Si}, \mathrm{Ti}, \mathrm{As}, \mathrm{Ba}, \mathrm{Cl}, \mathrm{Co}, \mathrm{Cr}, \mathrm{Cu}, \mathrm{Mo}, \mathrm{Nb}, \mathrm{Ni}, \mathrm{Pb}, \mathrm{Rb}, \mathrm{S}, \mathrm{Sn}, \mathrm{Sr}$, Th, V, W, Y, Zn and $\mathrm{Zr}$. At the time of writing the results of the analyses are awaiting further computer treatment.

\section{Results}

A few duplicate sediment silt samples were collected in 1985 at localities sampled in 1984 to control their reproducibility. The areas of southern Nares Land (fig. 2), Castle $\varnothing$ (fig. 3) and Stephenson $\varnothing$ (fig. 4) all show reasonably good correlation for both $\mathrm{Zn}$ and $\mathrm{BaO}$ between the samples from 1984 and those from 1985 (fig. 5). One stream in southern Nares Land differs in $\mathrm{BaO}$ values from $2995 \mathrm{ppm}$ (1984) to $5485 \mathrm{ppm}$ (1985) (fig. 2). The sample with the higher value was taken higher up the stream and thus, possibly, closer to the source of the $\mathrm{BaO}$ anomaly.

In north-west Nares Land the correlation is poor (fig. 5). Streams 1 and 3 (fig. 6) show the same trend for both $\mathrm{Zn}$ and $\mathrm{BaO}$, low 1984 values and high 1985 values, whereas stream 2 has high 1984 values and low 1985 values from 1985 (fig. 5). It is obvious that the values for $\mathrm{BaO}$ and $\mathrm{Zn}$ obtained in streams 1 and 3 in the 1984 samples are far too low compared to the 1985 average content. However, it is not yet possible to explain this difference, which might be due to different sampling sites, different types of material or analytical problems. The inverse problem applies to stream 2 , although the same factors as noted above could also apply there.

Detailed sampling of rocks was carried out in three different sedimentary successions: (1) in part of the Silurian slope sequence north of the platform margin in southern Nares Land to study high $\mathrm{BaO}$ contents; (2) in parts of the Silurian deep-water sequence (Larsen \& Escher, 1985) on Castle $\varnothing$, for investigation of $\mathrm{BaO}$ and $\mathrm{Zn}$ contents; (3) in the un-named

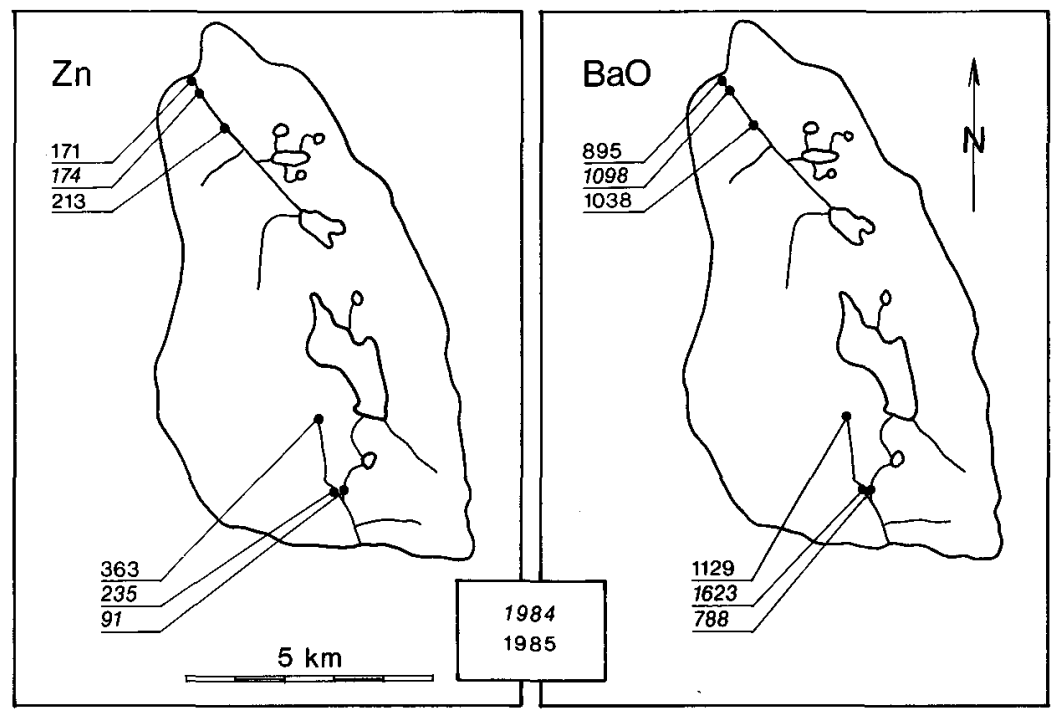

Fig. 3. Analytical values (ppm) for $\mathrm{Zn}$ and $\mathrm{BaO}$ in silt samples on Castle $\emptyset$. 


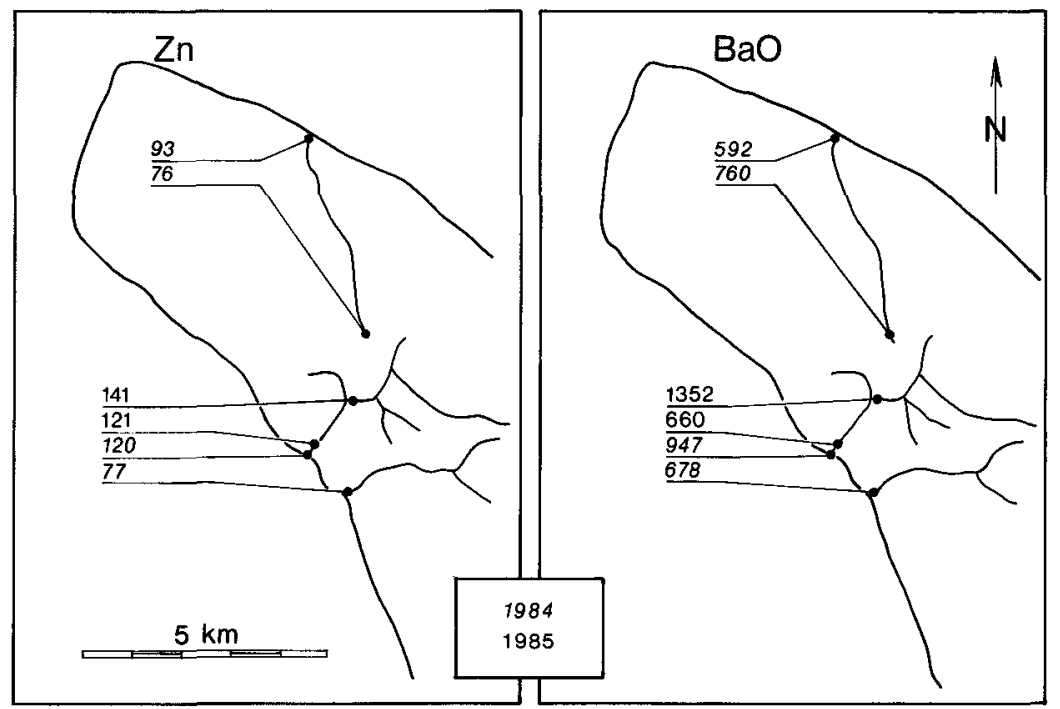

Fig. 4. Analytical values (ppm) for $\mathrm{Zn}$ and $\mathrm{BaO}$ in silt samples on Stephenson $\emptyset$.

Cambrian - Lower Silurian outer shelf and slope sequence (Higgins \& Soper, 1985; Davis \& Higgins, 1987) in Freuchen Land, north-west Nares Land, Stephenson $\emptyset$ and northern Nyeboe Land, to investigate anomalous $\mathrm{BaO}$ and $\mathrm{Zn}$ values. The stratigraphic profiles in some of these areas include the sub-Portfjeld Formation sequence, Portfjeld Formation, Buen Formation and Polkorridoren Group. Table 1 shows the number of samples taken in the various stratigraphic units at each locality.
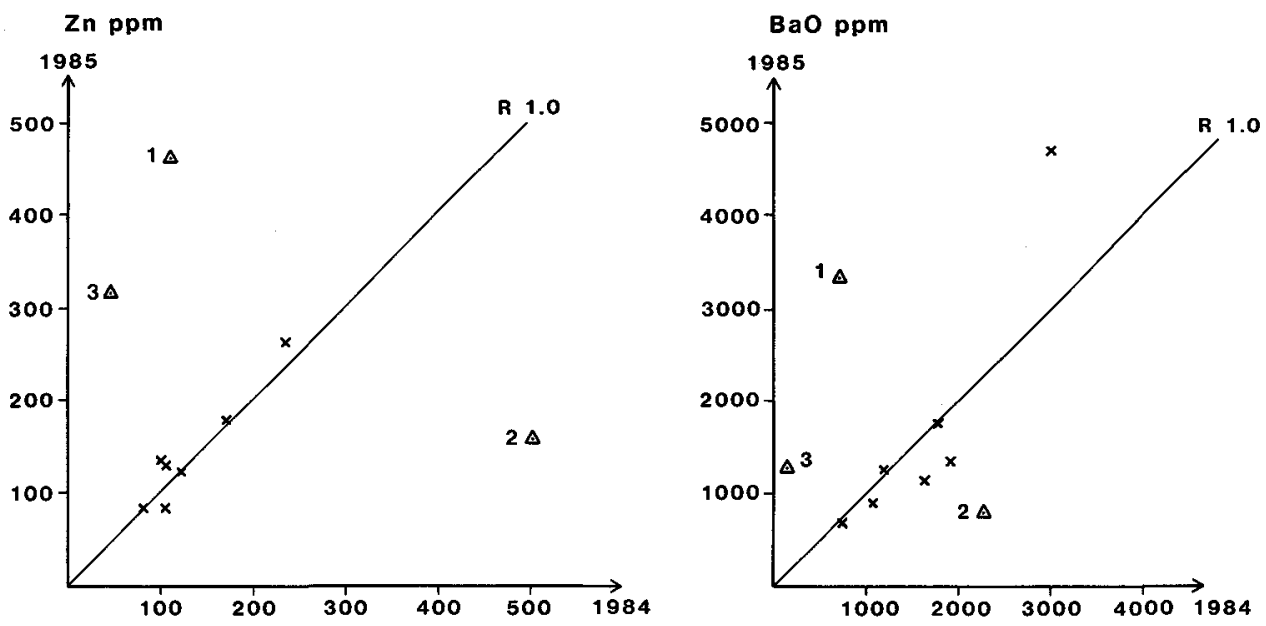

Fig. 5. Correlation for $\mathrm{BaO}$ and $\mathrm{Zn}$ in samples taken at the same localities in 1984 and 1985. The crosses represent samples from southern Nares Land, Castle $\emptyset$ and Stephenson $\emptyset$. Triangles $(1,2,3)$ represent samples from the northern part of Nares Land. Maximum correlation coefficient $(R=1.0)$ is indicated. 


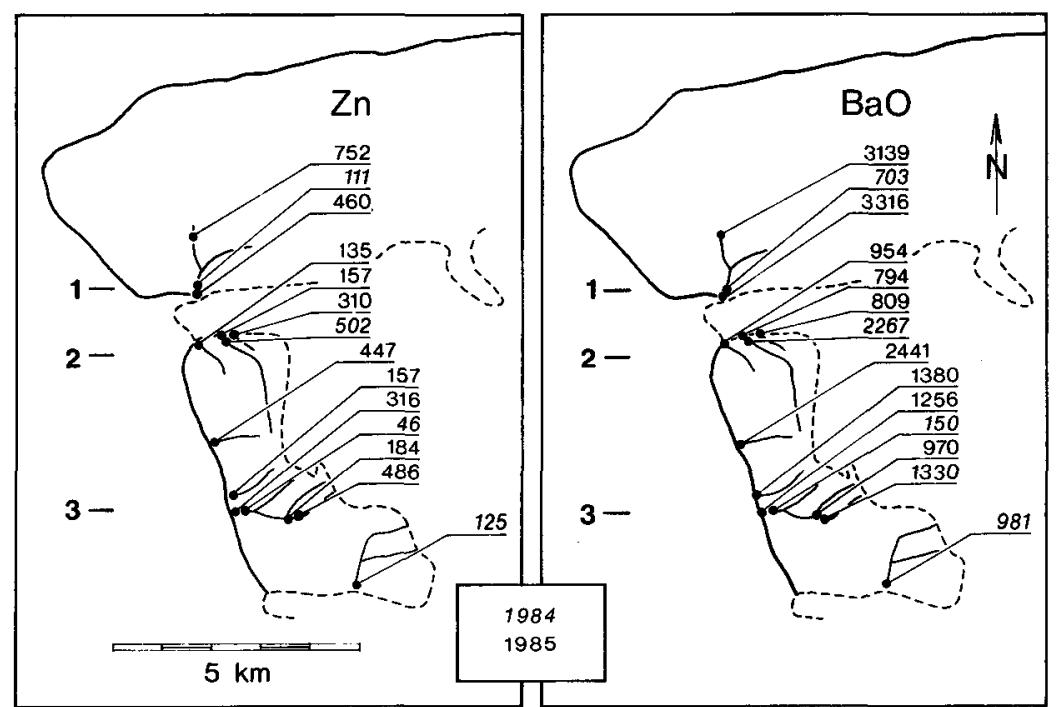

Fig. 6. Analytical values (ppm) for $\mathrm{Zn}$ and $\mathrm{BaO}$ in silt samples from northern Nares Land. Streams are numbered 1-3. See text for discussion.

\section{The Silurian slope sequence.}

In North Greenland the Silurian Lafayette Bugt Formation at the platform margin generally contains higher contents of $\mathrm{BaO}$ and $\mathrm{Zn}$ (Steenfelt, 1985) than the other formations. In southern Nares Land an anomalous $\mathrm{Ba}$ content with up to $0.3 \% \mathrm{BaO}$ was recorded in the 1984 stream sediment analyses. The Lafayette Bugt Formation comprises dark mudstones, siltstones and shales, intercalated with beds (centi- to decimetre thick) of mostly dark, bi-

Table 1. Number of samples for rock geochemistry collected in 1985

\begin{tabular}{|c|c|c|c|c|c|c|c|c|}
\hline \multicolumn{2}{|c|}{ Lithological units } & \multirow[t]{2}{*}{$\begin{array}{c}\text { Navarana } \\
\text { Fj. }\end{array}$} & \multirow{2}{*}{$\begin{array}{c}\begin{array}{c}\text { S Nares } \\
\text { Ld }\end{array} \\
48\end{array}$} & \multirow[t]{2}{*}{$\begin{array}{c}\text { NW Nares } \\
\text { Ld }\end{array}$} & \multirow[t]{2}{*}{$\begin{array}{c}\text { Stephenson } \\
\varnothing\end{array}$} & \multirow{2}{*}{$\underset{\varnothing}{\text { Castle }}$} & \multirow{2}{*}{$\begin{array}{l}\text { N Nyeboe } \\
\text { Ld }\end{array}$} & \multirow{2}{*}{$\begin{array}{r}\text { Total } \\
48\end{array}$} \\
\hline & (Lafayette Bugt Fm & & & & & & & \\
\hline Peary & Nordkronen Fm & & & & & 6 & & 6 \\
\hline Land & $\{$ Lauge Koch Ld Fm & & & & & 10 & & 10 \\
\hline \multirow{2}{*}{ Group } & Wulff Ld Fm & & & & & 4 & & 4 \\
\hline & Merqujôq Fm & & & 7 & 1 & & 1 & 9 \\
\hline \multirow{7}{*}{\multicolumn{2}{|c|}{$\begin{array}{l}\text { Un-named Unit } 4 \\
\text { shelf and unit } 2+3 \\
\text { slope seq. Unit } 1 \\
\text { Buen Formation } \\
\text { Polkorridoren Group } \\
\text { Portfjeld Formation } \\
\text { Sub-Portfjeld sequence }\end{array}$}} & 10 & & 14 & 1 & & 7 & 32 \\
\hline & & 9 & & 5 & 2 & & 10 & 26 \\
\hline & & 4 & & 19 & 1 & & 4 & 28 \\
\hline & & 3 & & 6 & 3 & & & 12 \\
\hline & & & & & & & 3 & 3 \\
\hline & & & & & 6 & & & 6 \\
\hline & & & & & 3 & & & 3 \\
\hline & & 26 & 48 & 51 & 17 & 20 & 25 & 187 \\
\hline
\end{tabular}

The lithological units are indicated on the stratigraphic scheme in the first article in this report

(Henriksen, 1987, fig. 3). 
tuminous and fossiliferous conglomeratic limestones. The conglomeratic limestones have a strong smell of hydrocarbon and have tar-like residues as pore fillings. The conglomeratic limestone horizons are laterally persistent and contain small amounts of galena, and probably also baryte. The shales typically contain disseminated pyrite, and darker shales also contain pyrite concretions of centimetre size and thin layers (millimetre size) of pyrite. The concretions and layers of pyrite are concentrated in thin (centi- to decimetre thick) shale bands at certain levels, and are normally laterally persistent. At one locality galena was also recorded in shale. The source for the enhanced and anomalous $\mathrm{Ba}$ content of drainage sediments may be the limestone conglomerates and/or the pyritiferous beds in the sequence, but this cannot be conclusively demonstrated.

\section{The Silurian deep-water turbidite sequence.}

Generally high contents of $\mathrm{Ba}, \mathrm{Pb}$ and $\mathrm{Zn}$ were found in 1984 drainage sediments derived from the Silurian Peary Land Group (Steenfelt, 1985). The Peary Land Group on Castle $\varnothing$ yielded two anomalous stream sediment samples in 1984 with high contents of $\mathrm{Zn}$ and $\mathrm{BaO}$. The two main streams (fig. 3) are confined to geological lineaments striking more or less $\mathrm{N}-\mathrm{S}$. These lineaments today form valleys with exposures of the Lauge Koch Land, Wulff Land and Nordkronen Formations. The Lauge Koch Land Formation consists of medium to thick bedded sandstone turbidites with thinner bedded siltstone and mudstone. In the Wulff Land Formation black mudstones dominate, while the Nordkronen Formation consists largely of resedimented chert pebble conglomerate (Larsen \& Escher, 1985). The chert conglomerate is in places veined by calcite/quartz veins with blebs of pyrite. The fine sandstone turbidites occasionally contain disseminated or fine-grained stratabound pyrite. There is no clear indication of the source of the high $\mathrm{BaO}$ and $\mathrm{Zn}$ values, except for a general higher than average content of these elements in one or more of the lithological units.

\section{The Cambrian - Lower Silurian outer shelf and slope sequence.}

This un-named succession (Higgins \& Soper, 1985; Davis \& Higgins, 1987) has been the subject of an intensive geochemical investigation because of the many anomalous $\mathrm{BaO}$ and $\mathrm{Zn}$ localities detected during analysis of the 1984 drainage sediments (Steenfelt, 1985). Values of up to $0.4 \% \mathrm{BaO}$ and up to $500 \mathrm{ppm} \mathrm{Zn}$ have been recorded in the stream sediment samples. Furthermore the heavy mineral concentrates in some of the sand samples (1984) are characterised by high contents of sphalerite and galena. The sequence which is $300-400$ $\mathrm{m}$ thick in the examined profiles (Table 1) has been divided into 4 units by Higgins \& Soper (1985).

The lower $100 \mathrm{~m}$ of the sequence (unit 1 ) is built up of brown-green, normally centimetre thick, shales and carbonates. Pyrite is often disseminated in the shales or found as centimetre-size concretions. Nodular dolomite concretions of centi- to decimetre size are common in this part of the section. Unit 2 in Nyeboe Land is a $25 \mathrm{~m}$ thick black shale sequence with some fine-grained sandstone beds containing stratabound lamina of pyrite $(0.5 \mathrm{~mm}$ or less thick) in the shales. Unit 3 (100-200 m thick) includes several 5-20 m beds of intraformational carbonate breccias, interdigitated with dolomite mudstone, shale and interbanded yellow dolomite and grey limestone (Higgins \& Soper, 1985; Davis \& Higgins, 1987). Very finegrained pyrite is normally abundant in the black shales of this sequence. The upper part 
(c. $100 \mathrm{~m}$ ) of the sequence corresponds to unit 4 and consists of black cherts and cherty shales. The chert proportion is greatest on Nares Land where parts of the carbonate sequence of unit 3 are replaced by chert beds. The chert often has a rusty appearance, but it has proved impossible to detect sulphides in these microcrystalline rocks.

Quartz and calcite veins are common in the intraformational carbonate breccias, both as veinlets and metre thick veins. A few grains of sphalerite and galena were found in these veins in north-west Nares Land. In the eastern part of the region, in Freuchen Land, calcite veins dominate, while in Nares Land mixed calcite and quartz veins are common, and in the western part of the region, in Nyeboe Land, quartz veins are characteristic.

$\mathrm{High} \mathrm{BaO}$ and $\mathrm{Zn}$ contents in the stream sediments are due to a natural high content of $\mathrm{Ba}$ and $\mathrm{Zn}$ in the adjacent lithologies. The pyritiferous black shale in unit 2 could also be the cause of the raised values, as stratabound pyrite concentrations normally contain higher contents of associated elements such as $\mathrm{Zn}$ and $\mathrm{Ba}$. The few grains of sphalerite and galena observed in the quartz/calcite veins are so rare that the anomalous values in the stream sediments probably are not caused by these alone.

\section{Summary and conclusion}

After the 1985 field season the drainage sampling programme in North Greenland is now complete with an average density of one sample per $25 \mathrm{~km}^{2}$. The reproducibility of the sampling between 1984 and 1985 has in general been good (fig. 2-5) except for one locality in north-west Nares Land (figs $5 \& 6$ ).

The sphalerite mineralisation found in 1984 in Navarana Fjord, eastern Freuchen Land (Jakobsen \& Steenfelt, 1985), contained baryte in addition to sphalerite. This vein-type mineralisation has not been recognised in other areas with a similar geological setting, even though the indications from the 1984 geochemical drainage data were promising.

Stratabound pyrite accumulations occur in the upper part of the Buen Formation in greenish brown shales, and in parts of the un-named shelf and slope sequence in black cherty shales. It is possible that the $\mathrm{Ba}$ and $\mathrm{Zn}$ anomalies are related to these pyrite-bearing lithostratigraphic levels, or the content of these elements in this part of the sequence may simply be high.

The most promising anomalies in North Greenland are those associated with the so-called un-named shelf and slope sequence (Steenfelt, 1985). Comparable sequences elsewhere in the world have contained economic deposits. For example, major stratiform pyrite/baryte deposits with local high grade concentrations of sphalerite and, to a lesser extent, galena have been located in north-east British Columbia (Gataga district: MacIntyre, 1983; Cirque baryte-zinc-lead deposit: Jefferson et al., 1983) and in the south-east Yukon Territory. The baryte-sulphide deposits of north-east British Columbia occur in cherts and black silty shales (MacIntyre, 1983). The conditions of sedimentation and structural development in British Columbia are comparable to those in North Greenland. The prerequisites for the empiric model for submarine-exhalative stratiform baryte-sulphide deposits listed by Large (1980) are present to some extent in North Greenland; these include sedimentary environment, fine-grained sulphide minerals concordant with the bedding, and minor stockwork and/or vein-type mineralisation. Baryte in this type of deposit is fine-grained, thinly interbedded with sulphides or occurs as massive sulphide-baryte ore (Large, 1980). 
Acknowledgements. The success of the sampling programme was to a large extent due to the skill of the two Swiss helicopter pilots, Karl Isler and Urs Stoller, who are acknowledged for their encouragement and patience during the sampling.

\section{References}

Davis, N. C. \& Higgins, A. K. 1987: Cambrian - Lower Silurian stratigraphy in the fold and thrust zone between northern Nyeboe Land and J. P. Koch Fjord, North Greenland. Rapp. Grønlands geol. Unders. 133, 91-98.

Henriksen, N. 1987: Systematic geological mapping in 1985 in central and western North Greenland. Rapp. Grønlands geol. Unders. 133, 5-12.

Higgins, A. K. \& Soper, N. J. 1985: Cambrian - Lower Silurian slope and basin stratigraphy between northern Nyeboe Land and western Amundsen Land, North Greenland. Rapp. Grønlands geol. Unders. 126, 79-86.

Jakobsen, U. H. \& Steenfelt, A. 1985: Zinc mineralisation at Navarana Fjord, central North Greenland. Rapp. Grønlands geol. Unders. 126, 105-109.

Jefferson, C. W., Kilby, D. B., Pigage, L. C. \& Roberts, W. J. 1983: The Cirque barite-zinc-lead deposits, northeastern British Columbia. In Sangster, D. F. (edit.) Short course in sediment-hosted stratiform lead-zinc deposits, 121-140. Mineralogical Association of Canada.

Large, D. E. 1980: Geological parameters associated with sediment-hosted, submarine exhalative $\mathrm{Pb}-\mathrm{Zn}$ deposits: an empirical model for mineral exploration. Geol. Jb. D40, 59-129.

Larsen, P.-H. \& Escher, J. C. 1985: The Silurian turbidite sequence of the Peary Land Group between Newman Bugt and Victoria Fjord, western North Greenland. Rapp. Grønlands geol. Unders. 126, 47-67.

MacIntyre, D. G. 1983: Geology and stratiform barite-sulphide deposits of the Gataga district, northeast British Columbia. In Sangster, D. F. (edit.) Short course in sediment-hosted stratiform lead-zinc deposits, 85-119. Mineralogical Association of Canada.

Steenfelt, A. 1985: Reconnaissance scale geochemical survey in central and western North Greenland. Preliminary results concerning zinc and barium. Rapp. Grønlands geol. Unders. 126, 95-104. 